\title{
BIBLIOTEKI BRAJLOWSKA I CZARNODRUKOWA ZAKŁADU DLA NIEWIDOMYCH W LASKACH
}

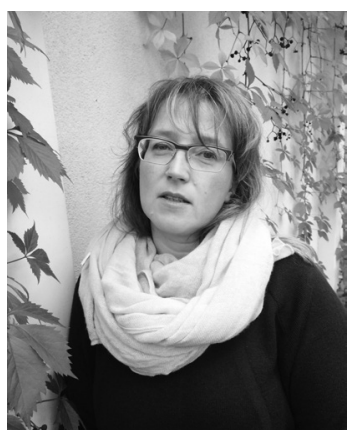

Główne zainteresowania badawcze: funkcjonowanie ruchu wydawniczego i księgarskiego w latach 1945-1956 w Polsce; biblioteki w Polsce w latach 1945-1956; kolekcje, księgozbiory i biblioteki z XIX w.; współczesne media w Polsce, szczególnie prasa, terapia czytelnicza.

W dorobku kilkadziesiąt artykułów w czasopismach naukowych i pracach zbiorowych oraz książki Biblioteka, której nie ma... Andrzej Edward Koźmian i jego ksiażki (2015) i Bajka jak lekarstwo. Zastosowanie bajkoterapii w terapii pedagogicznej (2015, współautorstwo). Współredakcja książek Na co dzień i od święta. Książka w życiu Polaków w XIX-XXI wieku (Warszawa, 2015) oraz Policies, their Implementation and Results (Frankfurt am Main, 2015). Od 2008 r. sekretarz czasopisma naukowego „Z Badań nad Książką i Księgozbiorami Historycznymi".

SŁOWA KLUCZOWE: Zakład dla Niewidomych w Laskach. Biblioteka brajlowska. Biblioteka czarnodrukowa. Czytelnicy z niepełnosprawnością wzroku. Książka brajlowska. Czytelnictwo.

ABSTRAKT: Teza/cel artykułu - Biblioteki brajlowska i czarnodrukowa Zakładu dla Niewidomych w Laskach są placówkami pełniącymi jednocześnie funkcje i zadania bibliotek publicznych, jak i szkolnych, z nastawieniem na obsługę czytelników z niepełnosprawnością wzroku. Ich użytkownikami są zarówno uczniowie różnych typów szkół, jak i nauczyciele, wychowawcy i inni pracownicy laskowskich placówek (także emerytowani) oraz ich rodziny, co przekłada się na zawartość księgozbiorów obu bibliotek, których cechą charakterystyczną jest duża rozpiętość tematyki i poziomu książek. Celem artykułu jest przedstawienie pracy obu bibliotek w aspekcie placówek świadczących usługi osobom z niepełnosprawnością wzroku, a także problemów i zadań, przed którymi stoją w dobie Internetu, szybkiego rozwoju tyfloinformatyki oraz spadającego czytelnictwa, w tym szczególnie czytelnictwa ksią- 
żek brajlowskich. Metody badań - Współczesna działalność placówek została oceniona wg wzorca biblioteki dostosowanej do obsługi osób niepełnosprawnych uwzględniającego: lokal biblioteczny wraz z wyposażeniem, zbiory biblioteczne, technologie wspomagające i usługi biblioteczne oraz kwalifikacje pracowników. Pracę obu bibliotek przedstawiono w artykule wykorzystując metodę analizy źródeł i opracowań, przy szczególnym wykorzystaniu dokumentacji bibliotecznej, zwłaszcza zachowanych protokołów i sprawozdań. W skróconej formie została omówiona historia placówek oraz ich obecna działalność. Przy ocenie ich pracy jako bibliotek specjalnych, świadczących swoje usługi głównie osobom z niepełnosprawnością wzroku, wykorzystano przede wszystkim wzorzec zaproponowany przez Małgorzatę Fedorowicz oparty na rozwiązaniach światowych oraz wskazania IFLA (Fedorowicz, 2010). Wyniki i wnioski - Działalność bibliotek czarnodrukowej i brajlowskiej Zakładu dla Niewidomych w Laskach jest specyficzna, bo wychodzi poza ścisłą działalność edukacyjno-wychowawczą laskowskich szkół. Czytelnikami obu bibliotek są nie tylko uczniowie, ale także ich nauczyciele, wychowawcy i inni pracownicy laskowskich placówek (także emerytowani) oraz ich rodziny - osoby w różnym wieku, o różnym poziomie wykształcenia, potrzebach i zainteresowaniach. Biblioteki pełnią w związku z tym jednocześnie funkcje i zadania bibliotek publicznych i szkolnych, nastawionych przede wszystkim na czytelnika z niepełnosprawnością wzroku, a więc w swojej istocie placówek specjalnych. To przekłada się na zawartość ich księgozbiorów, których cechą charakterystyczną jest duża rozpiętość tematyki i poziomu książek. W dobie Internetu, szybkiego rozwoju tyfloinformatyki oraz spadającego czytelnictwa, w tym szczególnie książek brajlowskich, obie placówki stanęły przed nowymi wyzwaniami związanymi również z oczekiwaniami użytkowników, nastawionych na łatwy dostęp do informacji nieograniczony w czasie i przestrzeni oraz w dogodnym dla nich właściwym formacie.

\section{WPROWADZENIE}

Powstanie obu bibliotek jest ściśle związane z osobą Róży Czackiej, ociemniałej inicjatorki i współzałożycielki w 1911 r. Towarzystwa Opieki nad Ociemniałymi (TOnO) (s. Cecylia, 1991; Żółtowski, 1999; Gościmska, 2014)². Czacka powołanie $\mathrm{TOnO}^{2}$ poprzedziła gruntownymi, trwającymi dziesięć lat, zagranicznymi studiami nad sprawą niewidomych (Czacka, 1935; Statut..., 1911; Wyrzykowska, 2002; Przybył-Sadowska, 2015). Przenosząc na grunt polski zagraniczne rozwiązania wzorowała się na stowarzyszeniu Comité Valentin Haüy de Nice, założonym przez Mauricéa de la Sizeranne (Villey, 1977), które, jej zdaniem, dawało najpełniejszą, wszechstronną opiekę nad niewidomymi. Jednym z ważnych jej aspektów była nauka pisania i czytania pisma Braille'a, zakładanie bibliotek brajlowskich oraz wydawanie książek brajlowskich.

\footnotetext{
${ }^{1}$ Róża Czacka (1876-1961) przywdziała habit zakonny i przybrała imię Elżbieta w 1917 r., a w następnym roku założyła Zgromadzenie Sióstr Franciszkanek Służebnic Krzyża.

${ }_{2}$ Pierwszy zakład dla niewidomych, wtedy jeszcze społeczny, Czacka założyła w 1910 r. w Warszawie, Statut TOnO został zatwierdzony przez władze carskie w 1911 r. Od 1922 r. działy TOnO były stopniowo przenoszone do Lasek pod Warszawą. W Warszawie do II wojny światowej działało m.in. Biuro Przepisywania Książek (BPK).
} 
W okresie międzywojennym m. Elżbieta Róża Czacka, uznawana współcześnie za pierwszego polskiego tyflologa (Rakowska, 2007, s. 866; Kuczyńska-Kwapisz, 2011; Gościmska, 2014), pracowała nad adaptacją systemu Braille'a do języka polskiego, a następnie wraz z s. Teresą Landy także nad 3-stopniowym systemem skrótów ortograficznych (Zarządzenie..., 1934; Czacka, Landy, 1931). Domagała się także uporządkowania spraw związanych z prowadzeniem bibliotek brajlowskich w ówczesnej Polsce. Sama proponowała, na wzór idei „bibliotek wędrownych” Heleny Radlińskiej (Radlińska, 1922), powołanie systemu opartego na centralnej bibliotece i sieci powiązanych z nią oddziałów terenowych z wymiennym księgozbiorem (Czacka, 2008, s. 148-149). Jej pomysł zrealizowało TOnO, uruchamiając oddziały biblioteczne w tzw. patronatach (placówki opieki otwartej nad niewidomymi i ich rodzinami) w Chorzowie, w Warszawie, w Krakowie i w Poznaniu, które dysponowały księgozbiorem liczącym ok. 300 tomów (Sprawozdanie... 1936/1937; Laski..., 1938, s. 26-31; Czerwińska, 1999, s. 44).

\section{POWSTANIE I DZIAŁALNOŚĆ BIBLIOTEKI BRAJLOWSKIEJ DO II WOJNY ŚWIATOWEJ}

Biblioteka brajlowska powstała wraz z utworzeniem w 1911 r. TOnO, dzięki staraniom Czackiej, która zaczęła organizować przepisywanie książek (później funkcjonujące jako Biuro Przepisywania Książek), jeszcze zanim formalnie powstało Towarzystwo. Zapewne także wtedy powstawała biblioteka czarnodrukowa. Biuro Przepisywania Książek (BPK) oparte było na pracy społecznych kopistek, a dla osób niewidomych praca w nim była źródłem utrzymania (Chamera-Nowak, 1998, s. 62-67). Sprawozdania z pierwszych lat działalności TOnO podaja, że w 1912 r. liczyła ona 128 dzieł i miała 25 czytelników, a w następnym 1913 r. już 248 dzieł w 427 tomach i 32 czytelników (Rocznik..., 1913; Rocznik... 1914).

Książki przepisywano według instrukcji Objaśnienie pisowni dla ociemniałych napisanej przez Czacka, wydanej przez TOnO w 1913 r., a następnie według kolejnej wersji z 1930 r. zatytułowanej Prawidła przepisywania ksią̇̇ek dla niewidomych (Czacka, 1913; Czacka, 1930). Kopiści przepisywali książki wskazane przez BPK. Oczywiste jest, że ze względu na cechy formalno-wydawnicze książki brajlowskiej oraz sposób jej produkcji nie jest możliwe przepisanie wszystkich książek czarnodrukowych (Czerwińska, 1999, s. 19-28, 63-64; Czerwińska, 2003a, s. 121-139; Czerwińska, 2003b, s. 849-858). Listy książek do przepisywania przygotowywała specjalna komisja TOnO, obecnie książki do przepisania wybiera kierowniczka Działu Braille'a, uwzględniając potrzeby laskowskich szkół.

W 1927 r. swoją siedzibę w nowo wybudowanym Domu Chłopców (szkoła i internat) w Laskach znalazła również biblioteka brajlowska wraz z biblioteką czarnodrukowa, podręczników i tyflologiczna, muzeum szkolnym, 
warsztatami i drukarnią brajlowską. Po I wojnie światowej prace BPK wznowiono w Warszawie dopiero w 1929 r. Przed wybuchem II wojny światowej, w 1938 r. pracowało w nim 85 kopistek, a biblioteka brajlowska liczyła 1774 dzieła w 5060 tomach (Laski..., 1938, s. 6).

Dla porównania biblioteka Association Valentin Haüy miała wówczas około 200 tys. tomów. W okresie międzywojennym biblioteka brajlowska w Laskach była największą i najprawdopodobniej jedyną w Polsce. Natomiast w drukarni działającej od 1927 r. w Laskach metodą stereotypii brajlowskiej drukowano przede wszystkim podręczniki szkolne, elementarze, czytanki, śpiewniki, modlitewniki (Laski..., 1938, s. 6-8)3.

\section{DZIAŁALNOŚĆ BIBLIOTEKI BRAJLOWSKIEJ OD 1945 ROKU DO CZASÓW WSPÓŁCZESNYCH}

Niestety, w wyniku działań wojennych spłonęły w 1939 r. biblioteki: czarnodrukowa (licząca 7 tys. tomów), podręczników i tyflologiczna, a także drukarnia brajlowska oraz muzeum szkolne (Wyrzykowska, 2002 s. 56). Biblioteka brajlowska, która ucierpiała w mniejszym stopniu, działała przez całą wojnę „ukryta” w sali z podpartymi stropami i napisem na drzwiach „lokal grozi zawaleniem" (Gościmska, 1982, s. 36). Od połowy lat 50. XX w. biblioteka mieściła się w baraku, a w $1993 \mathrm{r}$. została przeniesiona do nowo wybudowanego budynku, gdzie obecnie znajduje się oprócz niej także biblioteka czarnodrukowa, wypożyczalnia kaset ${ }^{4}$, dział wydawniczy oraz introligatornia.

W 1945 r. biblioteka brajlowska liczyła przeszło 1200 dzieł w 3200 tomach (Wyrzykowska, 2002, s. 89), a na koniec 2016 r. - 5837 tytułów w 18087 tomach (Sprawozdanie z pracy Biblioteki Brajlowskiej..., 2016). Księgozbiór w latach 2003-2016 zasilany był średnio 60 tytułami rocznie, głównie przez produkcję własną TOnO, czyli książkami przepisanymi przez dział wydawniczy (Chamera-Nowak, 2016), darami (od wydawnictw np. Print 6, PHU Impuls, Toccata) oraz sporadyczne zakupami (Sprawozdania z pracy Biblioteki Brajlowskiej..., 1973-2016). W okresie od czerwca 2016 do stycznia 2017 r. zostało przeprowadzone pierwsze od wielu lat skontrum zbiorów, które wykazało, że biblioteka liczy 18087 woluminów.

Biblioteka posiada katalog alfabetyczny i tytułowy czarnodrukowy oraz alfabetyczny i rzeczowy katalog brajlowski, w którym zastosowano podział na cztery działy: książki dla dzieci i młodzieży, książki dla dorosłych, książki popularnonaukowe oraz książki religijne, które są wyróżnikiem tej biblioteki.

\footnotetext{
${ }^{3}$ W latach 1927-1938 wydrukowano 2106 tomów oraz około tysiąca drobnych druków.

${ }^{4}$ Była to swego czasu filia Biblioteki Centralnej Polskiego Związku Niewidomych. Znajdujące się $\mathrm{w}$ niej na stałe kasety zostały przekazane TOnO. Obecnie nie zasila się jej już kasetami wypożyczanymi czasowo z biblioteki PZN, ta bowiem w 2013 r. została włączona w strukturę Głównej Biblioteki Pracy i Zabezpieczenia Społecznego Ministerstwa Pracy i Polityki Społecznej. Wypożyczalnia kasetowa, która czeka na uporządkowanie, nie jest brana pod uwagę w niniejszym artykule.
} 
Dopływ nowych książek do Biblioteki Brajlowskiej w latach 2003-2016

\begin{tabular}{|c|c|c|c|c|c|c|}
\hline \multirow{2}{*}{ Rok } & \multicolumn{2}{|c|}{ Dział wydawniczy TOnO } & \multicolumn{2}{c|}{ Dary } & \multicolumn{2}{c|}{ Kupno } \\
\hline & tytuły & tomy & tytuły & tomy & tytuły & tomy \\
\hline 2003 & 46 & 83 & 2 & 5 & - & - \\
\hline 2004 & 52 & 118 & - & - & 3 & 30 \\
\hline 2005 & 78 & 128 & - & - & 4 & 48 \\
\hline 2006 & 58 & 120 & 1 & 1 & - & - \\
\hline 2007 & 62 & 133 & - & - & - & - \\
\hline 2008 & 65 & 124 & 30 & 219 & - & - \\
\hline 2009 & 106 & 256 & 9 & 53 & - & - \\
\hline 2010 & 73 & 162 & 2 & 2 & - & - \\
\hline 2011 & 53 & 103 & 3 & 8 & - & - \\
\hline 2012 & 51 & 110 & 11 & 45 & - & - \\
\hline 2013 & 45 & 76 & 2 & 2 & - & - \\
\hline 2014 & 36 & 87 & 43 & 92 & - & - \\
\hline 2015 & 41 & 69 & 7 & 21 & - & - \\
\hline 2016 & 21 & 49 & - & - & - & - \\
\hline
\end{tabular}

Oprac. własne na podstawie sprawozdań z pracy Biblioteki Brajlowskiej za lata 2003-2016, mps.

Biblioteka Brajlowska, Laski.

Przed II wojną światową książki wypożyczane były w środy i w czwartki oraz w soboty (Regulamin..., 1931). Książki wysyłano także pocztą. Po wojnie do połowy lat 70. biblioteka czynna była dwa razy w tygodniu przez jedną godzinę - jednego dnia dla chłopców, drugiego dla dziewcząt.

Od 1975 r. biblioteka przyjmowała czytelników od poniedziałku do piątku, a następnie cztery razy $\mathrm{w}$ tygodniu. Obecnie ponownie czynna jest pięć dni w tygodniu. W bibliotece brajlowskiej nie ma wolnego dostępu do półek, wypożyczalnia znajduje się na parterze budynku, a magazyny na piętrze (książki przesyłane są wewnętrzną windą). Niektórzy czytelnicy korzystają z brajlowskiego katalogu alfabetycznego lub działowego, pozostałym z reguły doradza bibliotekarz.

Czytelnicy podzieleni są na dwie główne kategorie - dorośli i uczniowie, którzy dodatkowo podzieleni są wg szkół: szkoła podstawowa, gimnazjum, gimnazjum specjalne, liceum/technikum, szkoła zawodowa i szkoła zawodowa specjalna.

Z analizy sprawozdań z pracy Biblioteki Brajlowskiej za lata 1973-201655 wy-

${ }^{5}$ Od 1997 r. sprawozdania Biblioteki Brajlowskiej oraz Biblioteki Czarnodrukowej w skróconej for- 
Liczba czytelników i wypożyczeń w bibliotece brajlowskiej w latach 1973-2015

\begin{tabular}{|c|c|c|c|c|}
\hline Rok & Uczniowie & Dorośli & $\begin{array}{c}\text { Liczba } \\
\text { wypożyczeń }\end{array}$ & $\begin{array}{c}\text { Liczba wypożyczo- } \\
\text { nych tomów }\end{array}$ \\
\hline 1 & 2 & 3 & 4 & 5 \\
\hline 1973 & 220 & 67 & b.d. & b.d. \\
\hline 1975 & b.d. & b.d. & b.d. & b.d. \\
\hline 1975 & 200 & 62 & b.d. & b.d. \\
\hline 1976 & 200 & 80 & 4600 & 11500 \\
\hline 1977 & 210 & 80 & 4596 & 11490 \\
\hline 1978 & 200 & 80 & 3297 & 11490 \\
\hline 1979 & 210 & 70 & 4490 & 11250 \\
\hline 1980 & 210 & 70 & 4355 & 10950 \\
\hline 1981 & 190 & 80 & b.d. & b.d. \\
\hline 1982 & 190 & 80 & 3338 & 8345 \\
\hline 1983 & 190 & 80 & 4011 & 10027 \\
\hline 1984 & 180 & 70 & 3986 & 11958 \\
\hline 1985 & 180 & 60 & 3578 & 10734 \\
\hline 1986 & 200 & 60 & 3493 & 9000 \\
\hline 1987 & 200 & 40 & 3847 & 9617 \\
\hline 1988 & 200 & 40 & 3752 & 9380 \\
\hline 1989 & 180 & 25 & 3682 & 9205 \\
\hline 1990 & 160 & 25 & 3534 & 8835 \\
\hline 1991 & 160 & 25 & 3412 & 8530 \\
\hline 1992 & 140 & 25 & 3075 & 7688 \\
\hline 1993 & 140 & 30 & 2180 & 5450 \\
\hline 1994 & 140 & 30 & 3142 & 7855 \\
\hline 1995 & 134 & 40 & 3031 & 7577 \\
\hline 1996 & 151 & 34 & 2789 & b.d. \\
\hline 1997 & b.d. & b.d. & b.d. & b.d. \\
\hline 1998 & 145 & 32 & 2667 & b.d. \\
\hline 1999 & 179 & 41 & 2315 & 4630 \\
\hline 2000 & 128 & 37 & 2036 & 2062 \\
\hline 2001 & 142 & 40 & 2232 & 2725 \\
\hline 2002 & 152 & 48 & 1938 & 2257 \\
\hline 2003 & 135 & 39 & 1657 & 2156 \\
\hline 2004 & 146 & 47 & 1718 & 2049 \\
\hline
\end{tabular}




\begin{tabular}{|c|c|c|c|c|}
\hline 1 & 2 & 3 & 4 & 5 \\
\hline 2005 & 150 & 25 & 1705 & 1949 \\
\hline 2006 & 155 & 29 & 1424 & 1823 \\
\hline 2007 & 150 & 25 & 1345 & 1389 \\
\hline 2008 & 140 & 26 & 1332 & b.d. \\
\hline 2009 & b.d. & b.d. & b.d. & b.d. \\
\hline 2010 & 126 & 17 & 1453 & 1877 \\
\hline 2011 & 130 & 17 & 870 & 1602 \\
\hline 2012 & 110 & 13 & 1244 & 1426 \\
\hline 2013 & 120 & 25 & 808 & 981 \\
\hline 2014 & 129 & 30 & 647 & 647 \\
\hline 2015 & 98 & 18 & 509 & 613 \\
\hline 2016 & $67^{*}$ & b.d. & 471 & 586 \\
\hline
\end{tabular}

*uczniów i dorosłych

Oprac. własne na podstawie sprawozdań z pracy Biblioteki Brajlowskiej za lata 1973-2015, msp.

Dział Braille'a, TOnO w Laskach.

nika, że liczba czytelników oraz wypożyczeń systematycznie spada. Trzeba tutaj jednak wyraźnie zaznaczyć, że tendencja ta ma ścisły związek z liczbą uczniów uczących się danego roku w laskowskich szkołach oraz zwiększającym się stale procentem uczniów niedowidzących, którzy korzystają z biblioteki czarnodrukowej. W ostatnich latach w Ośrodku Szkolno-Wychowawczym w Laskach uczy się średnio ok. 250 dzieci i młodzieży. W latach 70. XX w. liczba czytelników wynosiła 200 uczniów i 80 osób dorosłych (większość zamiejscowych), a wypożyczeń - ok. 4 tys., tj. ok. 11,5 tys. tomów rocznie. Pod koniec lat 80 . i na początku lat 90. czytelników było ok. 180, w tym ok. 140 uczniów i 40 osób dorosłych. Odnotowywano ok. 3, 6 tys. wypożyczeń, wypożyczono ok. 9 tys. tomów rocznie. Ostatnie lata to ciagły systematyczny spadek liczby czytelników i wypożyczeń - np. w 2015 r. z biblioteki korzystało 98 uczniów i 18 osób dorosłych, a wypożyczeń odnotowano 509, wypożyczono 613 tomów, w 2016 r. z biblioteki skorzystało 67 osób, które wypożyczyły 401 tytułów w 586 tomach (Sprawozdania z pracy Biblioteki Brajlowskiej..., 1973-2016).

Dane ze sprawozdań nie są dokładne i nie oddają rzeczywistej sytuacji, bowiem często zawierają informacje orientacyjne, a wyliczenia nie są ujednolicone, co utrudnia porównanie danych. Początkowo podział czytelników był nieco inny, czyli na: czytelników z Lasek, tj. uczniów i dorosłych oraz na czytelników spoza Lasek. Natomiast od 1982 r. sprawozdania podają liczbę wypożyczeń uczniów poszczególnych szkół oraz dorosłych bez rozróżnienia, czy byli to czy-

mie zamieszczane są corocznie w czasopiśmie „Laski”, wydawanym przez TOnO, zwykle w numerze 3/4. Sprawozdania z wcześniejszych lat, niestety, nie zachowały się lub ich nie było. 
telnicy miejscowi czy zamiejscowi. Wśród czytelników dorosłych znajdują się pracownicy Lasek, absolwenci i inni niewidomi przebywający w placówkach TOnO, np. w Żułowie i Niepołomicach. Obecnie zamiejscowo wypożyczane są książki (za pośrednictwem poczty) jedynie niewidomym z placówki w Niepołomicach oraz jednej z absolwentek. Przed stanem wojennym wysyłano tygodniowo średnio 70 paczek z książkami do czytelników z całej Polski (Spisy..., 1970-1985). Dla porównania w 1973 r. czytelników było 67, w 2016 r. zaledwie kilku. W czasie stanu wojennego poczta w ogóle nie przyjmowała przesyłek z książkami brajlowskimi. Pod koniec lat 80 . nasiliły się problemy z dostarczaniem czytelnikom książek za pośrednictwem poczty. Przesyłki ginęły, były niszczone - np. paczki z książkami brajlowskimi przygniatano innymi ciężkimi paczkami lub w ogóle odmawiano przyjęcia takich nadań (Protokoły..., 1987; Sprawozdanie z działu Brajla..., 1988). Dane dotyczące liczby czytelników oraz wypożyczeń również nie są dokładne. W XXI w. jako liczbę wypożyczeń w sprawozdaniach podawano ogólną liczbę odwiedzin.

W 1918 r. m. Elżbieta Czacka wprowadziła obowiązek codziennego półgodzinnego czytania brajlem. Zwyczaj ten teoretycznie przetrwał do dzisiaj, ale nie jest przestrzegany. Po II wojnie światowej uczniowie zobowiązani byli do przeczytania trzech tomów tygodniowo z zastrzeżeniem, że nie mogą to być podręczniki. Obowiązek ten, choć często nieprzestrzegany, miał jednak wpływ na rozwijanie zainteresowań czytelniczych wśród wychowanków Lasek. S. Monika Bohdanowicz organizowała po II wojnie co 2-3 lata, najczęściej w maju z okazji Dni Książki i Prasy, szkolne konkursy czytelnicze dla uczniów klas VI-VIII szkoły podstawowej oraz uczniów szkoły zawodowej. Uczestnicy musieli przeczytać wcześniej przygotowany tekst oraz tekst nieprzygotowany, napisać brajlem recenzję wybranej książki, a także wykazać się dużą liczbą przeczytanych książek (Sprawozdanie z działalności Towarzystwa..., 1953). Organizowano również, sporadycznie, spotkania z autorami, np. Małgorzatą Musierowicz. Od połowy lat 70. zaprzestano w ogóle organizacji konkursów czytelniczych, a propagowaniem czytelnictwa zajęła się biblioteka czarnodrukowa. Obecnie biblioteka brajlowska koncentruje się prawie wyłącznie na bieżącej obsłudze czytelników i konserwacji zbiorów, nie prowadzi żadnych działań aktywizujących czytelników (Chamera-Nowak, 2006), przeprowadza natomiast co roku kilka lekcji bibliotecznych. W 2016 r. były to dwie lekcje - podczas pierwszej troje czytelników zostało zapisanych do biblioteki, a w trakcie drugiej lekcji uczniowie 2 klasy gimnazjum uczyli się korzystania ze słowników (Sprawozdania z pracy Biblioteki Brajlowskiej..., 1973-2016).

$\mathrm{Z}$ analizy sprawozdań rocznych wynika, że najbardziej aktywnymi czytelnikami biblioteki brajlowskiej są uczniowie szkoły podstawowej oraz szkoły zawodowej specjalnej. W połowie lat 70. powodzeniem cieszyły się książki historyczne z okresu II wojny światowej oraz powieści młodzieżowe: Nienackiego, Domagalika, czy Jurgielewiczowej. Młodsze dzieci interesowały książki o zwierzętach oraz opowiastki o przygodach dzieci (Sprawozdania z działalnoś- 
ci Biblioteki Brajlowskiej..., 1973-2016). Obecnie dzieci chętnie sięgają po książki Andrzeja Maleszki czy z serii „Ulysses Moore”, a młodzież - M. Musierowicz czy Anny Łaciny. Powodzeniem cieszą się książki fantastyczne. Dorośli są zainteresowani powieściami historycznymi, klasyką oraz literaturą faktu. Długi proces produkcji książki brajlowskiej powoduje, że książki cieszące się w danej chwili powodzeniem trafiają do biblioteki z dużym opóźnieniem. To we wcześniejszych latach powodowało, że wychowawcy czytali dzieciom książki w grupach internatowych. Obecnie dynamiczny rozwój nowych technologii tyfloinformatycznych spowodował wprawdzie przyspieszenie produkcji książki brajlowskiej, ale jest ona wypierana przez coraz powszechniejszy dostęp do książki mówionej w postaci cyfrowej oraz zmiany w nauczaniu z wykorzystaniem nowoczesnych technik (Kaczmarek, red., 2003; Paplińska, 2015a, s. $136-155 ; 2015 b$, s. 179-195).

\section{DZIAŁALNOŚĆ BIBLIOTEKI CZARNODRUKOWEJ}

Historia biblioteki czarnodrukowej (zwanej także szkolną lub zakładową) sięga początków powstania Zakładu w Laskach (Chamera-Nowak, 1998, s. 159). Korzystali z niej nauczyciele i inni pracownicy, a książki z jej zasobów służyły także do głośnego czytania niewidomym (Wyrzykowska, 2002, s. 31). Jak już wspomniano pierwsza biblioteka spłonęła w czasie kampanii wrześniowej 1939 r., a po II wojnie światowej rozpoczęto ponowne gromadzenie księ-

Dopływ nowych książek do biblioteki czarnodrukowej w latach 2005-2016

\begin{tabular}{|c|c|c|c|}
\hline Rok & Zakupy & Dary & Ogółem \\
\hline 2005 & 205 & 1345 & 1550 \\
\hline 2006 & 209 & 996 & 1205 \\
\hline 2007 & 197 & 1120 & 1317 \\
\hline 2008 & b.d. & b.d. & 351 \\
\hline 2009 & 293 & 183 & 476 \\
\hline 2010 & 178 & 92 & 270 \\
\hline 2011 & 176 & 209 & 385 \\
\hline 2012 & 54 & 152 & 206 \\
\hline 2013 & 65 & 121 & 186 \\
\hline 2014 & 109 & 155 & 264 \\
\hline 2015 & 50 & 347 & 397 \\
\hline 2016 & 146 & 236 & 382 \\
\hline
\end{tabular}

Oprac. własne na podstawie sprawozdań rocznych z działalności biblioteki czarnodrukowej za lata 2005-2015, mps. Biblioteka Czarnodrukowa, Laski. 
gozbioru. Na koniec 2016 r. księgozbiór główny liczył 23 528, a podręczników (w tym drukiem powiększonym) i broszur 8013 woluminów (Sprawozdania z działalności Biblioteki Czarnodrukowej..., 1981-2016). Księgozbiór gromadzony jest przede wszystkim drogą darów oraz zakupu. W ostatnich 10 latach średnio przybywało ok. 320 woluminów rocznie (Sprawozdania z działalności Biblioteki Czarnodrukowej..., 1981-2016).

Po wojnie biblioteka miała status biblioteki szkolnej ${ }^{6}$ i poddawana była, tak jak szkoły, częstym kontrolom wizytatorów kuratorium oświaty (Przybył-Sadowska, 2015, s. 92-96). Stąd też prowadzona była ona wzorowo i posiadała księgozbiór zgodny z wytycznymi władz komunistycznych. Książki potrzebne acz „niedozwolone” były wówczas na stanie biblioteki tyflologicznej podlegającej prezesowi TOnO, a tym samym nie narażonej na ciągłe kontrole wizytatorów ${ }^{7}$.

Specyfiką biblioteki czarnodrukowej, podobnie jak i brajlowskiej, jest to, że jej czytelnikami są zarówno dzieci i młodzież niedowidząca, jak i osoby dorosłe. Czytelnicy dorośli wypożyczają najchętniej biografie, literaturę faktu i książki historyczne, beletrystykę głównie tzw. czytadła, kryminały, książki religijne oraz różnego rodzaju poradniki (np. psychologiczne). Młodsze dzieci, oprócz lektur, chętnie sięgają po wierszyki, bajki i baśnie, a młodzież po fantastykę.

Na podstawie zachowanych sprawozdań z pracy biblioteki wynika, że najaktywniejszymi czytelnikami w latach 80 . i 90 . byli uczniowie ze szkoły podstawowej specjalnej, liceum, technikum i zasadniczej szkoły zawodowej (Sprawozdania z działalności Biblioteki Zakładowej..., 1981-2016). Obecnie są to uczniowie szkoły podstawowej i podstawowej specjalnej. Czytelnicy podzieleni są na dwie grupy: uczniowie szkół laskowskich i dorośli, czyli pracownicy z rodzinami, w tym z dziećmi. Liczba czytelników utrzymuje się od lat w granicach 400, z czego mniej więcej jedną czwartą stanowią uczniowie. Dokumentacja biblioteki, tj. sprawozdania, podobnie jak w przypadku biblioteki brajlowskiej, nie odzwierciedlają rzeczywistego stanu czytelnictwa ze względu na niejednolitość danych lub ich brak w poszczególnych sprawozdaniach, np. jako wypożyczenia rejestrowane były łącznie wypożyczenia i zwroty. Nie jest możliwe na ich podstawie stworzenie dokładnych statystyk. Biblioteka zanim przeniosła się w 1993 r. do nowego budynku, oprócz sporadycznych lekcji bibliotecznych oraz indywidualnych rozmów, nie prowadziła innych działań aktywizujących czytelników, czy promujących czytelnictwo. W latach

\footnotetext{
${ }^{6}$ Biblioteka brajlowska również była biblioteką szkolną, ale w 1948 r., gdy Urząd Bezpieczeństwa wywiózł, co najmniej kilkaset tomów książek autorów „zakazanych”, biblioteka ta została podporządkowana bezpośrednio prezesowi TOnO. W 1982 r. udało się odzyskać 45 tomów, tj. 8 tytułów wydanych w latach 1927-1942, które zostały wycofane ze zbiorów Biblioteki Narodowej. Korespondencja TOnO z dyrekcją Biblioteki Narodowej z 15.12.1981r., 29.12.1981 r. i 14 lipca 1982 r., mps., Dział Wydawniczy, TOnO, Laski.

7 Władze komunistyczne nie mogły znacjonalizować zakładu w Laskach, ponieważ był on instytucją społeczną, w związku z tym dążyły do likwidacji lub przynajmniej marginalizacji roli zakładu.
} 
1993-1994 zorganizowano dwie edycje konkursu czytelniczego „Moja mała książeczka" oraz spotkanie z poetką Ludwiką Amber, co zapewne było związane z nowym pomieszczeniem bibliotecznym. W kolejnych sprawozdaniach, jako pracę z czytelnikami wykazywano oprócz wypożyczania - poradnictwo bibliograficzno-biblioteczne, czyli przygotowywanie literatury przedmiotu, czytanie, dyktowanie lub notowanie informacji ze słowników, encyklopedii czy innych publikacji związanych z zadanym tematem. Jeszcze na początku XXI w. udzielano ok. 300 porad, a z czytelni korzystało rocznie ok. 300 czytelników. Obecnie wizyty w czytelni są sporadyczne. Odbywają się w niej przede wszystkim indywidualne zajęcia z uczniami. Biblioteka prowadzi wystawkę nowości oraz książek polecanych do przeczytania, a także organizuje okolicznościowe wystawki dotyczące bieżących wydarzeń kulturalnych. W 2003 r. czytano młodszym dzieciom bajki i opowiadania oraz na koniec roku szkolnego przyznano nagrody dla najlepszych czytelników. W latach 2003, 2004, 2006 prowadzono lekcje biblioteczne, a w 2006 r. zorganizowano spotkanie poetycko-muzyczne z Joanną Kulmową i Janem Kulmą. Kolejne spotkania autorskie powiązane z konkursami czytelniczymi zorganizowano dopiero w $2016 \mathrm{r}$. (z Grzegorzem Kasdepke i Stefanem Czernieckim). W 2016 r. biblioteka odnotowało 1811 odwiedzin czytelników oraz 1826 wypożyczeń. Średnia dzienna wypożyczeń wyniosła 9 woluminów (Sprawozdania z działalności Biblioteki Zakładowej..., 1981-2016).

BIBLIOTEKA BRAJLOWSKA I CZARNODRUKOWA JAKO PLACÓWKI ŚWIADCZĄCE USŁUGI OSOBOM Z NIEPEŁNOSPRAWNOŚCIĄ WZROKU

Obie laskowskie placówki mają długą tradycję i przez wiele lat dobrze spełniały swoje zadania jako placówki obsługujące osoby z niepełnosprawnością wzroku, w tym uczniów, absolwentów oraz pracowników. Jednak współcześnie przed bibliotekami tego typu stoją nowe wymagania oraz wyzwania. Zarówno te dotyczące dostępu fizycznego (otoczenia biblioteki, wejścia do niej, dostępu do materiałów i usług), form środków przekazu informacji, jak i usług oraz komunikacji (Zybert, 2007, s. 126-134). Zostały wypracowane wzorce uwzględniające: lokal biblioteczny wraz z wyposażeniem, zbiory biblioteczne, technologie wspomagające i usługi biblioteczne oraz kwalifikacje pracowników (Fedorowicz, 2010, s. 66-137; 2014, s. 410-419). W 2012 r. IFLA opublikowała na swojej stronie internetowej wykaz wskaźników dla bibliotekarzy pracujących z czytelnikiem niepełnosprawnym, którego autorami są członkowie IFLA Statistics and Evaluation Section i IFLA Libraries Serving Persons with Print Disabilities Section (Hardisty \& Mundt, 2012).

Wzorzec biblioteki dostosowanej do obsługi osób niepełnosprawnych uwzględnia: lokal biblioteczny wraz z wyposażeniem, zbiory biblioteczne, technologie wspomagające i usługi biblioteczne oraz kwalifikacje pra- 
cowników. Piętrowy budynek mieszczący obie omawiane biblioteki został specjalnie zaprojektowany na ich potrzeby (choć nie uniknięto błędów podczas budowy, np. wielkość okien na piętrze i sposób ich otwierania). Posiada łatwy i oznakowany dostęp dla osób niepełnosprawnych wzrokowo. Również same pomieszczenia biblioteczne dostępne dla czytelników są im przyjazne. Czytelnicy mają wolny dostęp do półek w bibliotece czarnodrukowej (regały są oznaczone napisami w kontrastowych kolorach -- czarny na żółtym i odpowiednio dużą czcionką), w brajlowskiej nie ma wolnego dostępu, ponieważ książki brajlowskie nie są podpisywane na okładkach (mają tylko sygnatury). Obie biblioteki są systematycznie zasilane nowymi książkami pochodzącymi głównie z darów, produkcji własnej i zakupów. Biblioteka brajlowska gromadzi książki brajlowskie obecnie jedynie pisane integrałem (w poprzednich latach także skrótami, tzw. laskowskimi, ale po wprowadzeniu w 1981 r. nowych skrótów, które okazały się za trudne, od uczniów nie wymaga się ich znajomości) (Józefowicz, Soloni, 1991). Należy tutaj podkreślić, że stałe zasilanie biblioteki brajlowskiej jest dużym wysiłkiem ze strony $\mathrm{TOnO}$, bowiem produkcja jednego tomu brajlowskiego kosztuje ok. 200 zł. Biblioteka czarnodrukowa z materiałów czytelniczych dla osób z niepełnosprawnością wzroku posiada podręczniki z powiększonym drukiem i niewielką liczbę, ok. 10 tytułów, książeczek tego typu. Żadna nie gromadzi nowoczesnych typów książek cyfrowych. Kasety z książkami mówionymi i audiobooki są na wyposażeniu wspomnianej wypożyczalni kaset.

Obie biblioteki udostępniają czytelnikom jedynie tradycyjne katalogi skrzynkowe, choć dla własnych potrzeb używają programów bibliotecznych, szczególnie biblioteka czarnodrukowa. Nie posiadają natomiast stron internetowych, a tym samym nie informują o swoich księgozbiorach za pomocą nowych technologii. Żadna z opisywanych bibliotek nie dysponuje również brajlowskimi urządzeniami elektronicznymi, np. typu czytak, ani nie ma dla czytelników stanowisk komputerowych wyposażonych w odpowiednie urządzenia peryferyjne (np. drukarki i monitory brajlowskie, skanery) wraz z oprogramowaniem tyfloinformatycznym. Przed laty na wyposażeniu czytelni czarnodrukowej były powiększalniki, ale zostały wycofane jako przestarzałe.

Ze świadczonych podstawowych usług bibliotecznych, w obu bibliotekach nie ma problemu z udostępnianiem zbiorów na miejscu. Obie czynne są pięć dni w tygodniu w godzinach rannych i wieczornych. Biblioteka brajlowska wysyła także pocztą książki czytelnikom zamiejscowym, choć wraz z rozwojem książki mówionej coraz mniej. $Z$ wymienionych powyżej powodów nie jest możliwe przesyłanie książek drogą elektroniczną.

Biblioteki właściwie nie oferują, poza wyjątkami, usług informacyjnych oraz w bardzo niewielkim stopniu pracują z czytelnikami. Praca z czytelnikami wsparta współpracą ze szkołami i internatami, właściwie poza krótkimi okresami nigdy, nie była silną stroną obu placówek. Już przed II wojną 
mocno kulała, co wynikało być może m.in. z trudnych warunków lokalowych oraz marginalnego traktowania pracy bibliotek, które wówczas ograniczało się praktycznie do udostępniania zbiorów (Czerwińska, 1999, s. 44-45). Nie przywiązywano także wagi do fachowego wykształcenia bibliotekarzy. I tak biblioteka brajlowska prowadzona była i jest przez osoby bez wykształcenia bibliotecznego (od $1993 \mathrm{r}$. jest to niewidoma wychowanka Lasek, Jadwiga Dąbrowska). Nieco lepiej było w bibliotece czarnodrukowej, gdzie okresami zatrudniano np. emerytowane wykwalifikowane bibliotekarki. Do tego problemem obu bibliotek zawsze były braki personalne. Od 1936 do 1975 r. biblioteką brajlowską, drukarnia, BPK i introligatornią kierowała Zofia Bohdanowicz, s. Monika (1892-1980), dr nauk medycznych UW. Po niej kierowanie Działem Braille'a przejęła niewidoma Jadwiga Broniec, s. Hieronima (ur. 1936), z wykształcenia teolog po KUL (Mazowiecki, red., 2000, s. 545). Od 2015 r., po reorganizacji, bibliotekami i działem wydawniczym kieruje Ewa Laske, s. Damiana (ur. 1970) posiadająca wykształcenie bibliotekarskie. W 2016 r. do działu wydawniczego zatrudniona została osoba niewidoma z wyższym wykształceniem bibliotekarskim, tyflologicznym i historycznym.

Obie placówki przez wiele lat nie współdziałały ze sobą w zakresie obsługi czytelników. Z przedstawionej analizy sprawozdań obu placówek wynika, że w niewielkim stopniu, oprócz formy indywidualnej, polegającej na doradztwie przy wyborze lektury, prowadzono pracę z czytelnikami. Inna forma pracy indywidualnej, przejawiająca się w pomocy w wyszukiwaniu i odczytywaniu informacji, zaniknęła w ostatnich latach. Czytelnia biblioteki czarnodrukowej zamieniała się, jak wspomniano, w salę, w której prowadzone są indywidualne zajęcia z uczniami. Na brak chętnych do korzystania z czytelni ma zapewne wpływ powszechna dostępność do słowników i encyklopedii w Internecie, wyposażenie w odpowiedni sprzęt komputerowy szkół, internatów oraz samych uczniów, a także braki w wyposażeniu czytelni w stanowiska komputerowe.

Z form poglądowych, które mają charakter informacyjny oraz promocyjny, korzysta jedynie biblioteka czarnodrukowa organizująca stałe wystawy nowości i książek wartych przeczytania oraz ścienne wystawy okolicznościowe. Z form pracy zbiorowej i zespołowej, czyli prelekcji, pogadanek, opowiadania bajek, konkursów, dyskusji - obecnie prowadzone są spotkania autorskie i związane z nimi konkursy oraz sporadycznie lekcje biblioteczne. Biblioteka brajlowska nie informuje o swoich zasobach, ani nie prowadzi żadnych innych działań zmierzających do nakłonienia do skorzystania z jej usług, stworzenia dobrego wizerunku czy zbudowania autorytetu. Nie jest to korzystne dla samej biblioteki oraz dla jej czytelników, szczególnie dzieci. Od 2015 r., gdy nadzór nad obiema bibliotekami przejęła s. Damiana Laske, sytuacja ta ulega powoli zmianie. Podjęto współpracę ze szkołami, w związku z wyborem książek przeznaczonych do przepisania. 


\section{PROBLEMY I ZADANIA STOJĄCE PRZED BIBLIOTEKAMI W DOBIE NOWYCH TECHNOLOGII TYFLOINFORMATYCZNYCH}

W przypadku obu bibliotek, ze względu na działanie przy ośrodku szkolno-wychowawczym konieczna jest zsynchronizowana współpraca wzajemna oraz współpraca ze szkołami i internatami. Tym bardziej, że istotnym problemem poruszanym przez tyflopedagogów w ostatnich latach jest zagrożenie osób niewidomych wtórnym analfabetyzmem, wynikające z przejścia z czytania brajlem jedynie na formy mówione (Gorajewska \& Paplińska, 2007, s. 79-80; Jakubowski, 2005, s. 156-158; Czerwińska, 2004, s. 101-126; 2011, s. 173-188) oraz zanik umiejętności czytania brajlem (Paplińska, 2005, s. 174-181; 2008, s. 53-62; Gorajewska \& Paplińska, 2007, s. 79-80). Do tego pojawia się problem ogólnego spadku czytelnictwa spowodowanego pojawieniem się nowych cyfrowych rozrywek w tym Internetu i gier komputerowych (Paplińska, 2005, s. 174-181; 2008, s. 53-62; 2015b, s. 179-195). Młode osoby z dysfunkcją wzroku często nie rozumieja, jak bardzo potrzebna jest im znajomość brajla, skoro nowoczesne technologie oparte na syntezie mowy w zupełności zaspokajają ich potrzeby komunikacyjno-informacyjne (Czerwińska, 2015, s. 374-377; Paplińska, 2015a, 144-145). Znajdują się one w paradoksie informacyjnym, który polega na tym, że posiadają dużą wiedzę o skutecznym wykorzystywaniu nowych technologii, a jednocześnie spada ich umiejętność czytania i pisania8. Małgorzata Paplińska zauważa również, że niewidomi używają wprawdzie nowych technologii, ale na poziomie podstawowym, np. komunikacji za pośrednictwem SMS-ów, czy mediów społecznościowych, a mają problem z wykorzystaniem ich bardziej rozbudowanych możliwości do edukacji czy pracy. Specjaliści wskazują przy tym na ogromny problem związany z dostępem do informacji osób niepełnosprawnych prowadzący do wykluczenia informacyjnego, którego konsekwencją jest wykluczenie społeczne. Osoby z niepełnosprawnością wzroku należą do grupy, która napotyka największe bariery w pozyskiwaniu informacji. Rozwój technologii wspomagających (urządzenia i oprogramowanie) spowodował, że osoby te wprawdzie mogą samodzielnie odczytać dowolny tekst, ale technologie te są drogie, więc nie wszystkich stać na nowoczesny sprzęt komputerowy i oprogramowanie. Poza tym tylko niewielki procent stron internetowych w pełni odpowiada standardom dostępności sieci dla osób niepełnosprawnych, a dostępne $\mathrm{w}$ sieci pliki nie zawsze są $\mathrm{w}$ formatach, które można odczytać poprzez syntezatory mowy (Adaszyńska \& Kuncewicz, 2013, s. 51-71, Fedorowicz-Kruszewska \& Cyrklaff, 2016, s. 127-136). Tym większa jest rola bibliotek, które powinny zapewnić dostęp osób niepełnosprawnych wzrokowo do zbiorów w nowoczesnych formatach al-

${ }^{8}$ Definicja Johna Faherty za M. Paplińską (2015a), s. 144. 
ternatywnych poprzez nowe technologie, sprzęt i oprogramowanie, np. programy odczytu ekranu, syntezatory mowy, programy komputerowe powiększające znaki na ekranie, powiększalniki ekranowe, programy ubrajlawiajace, monitory brajlowskie, drukarki brajlowskie, skanery oraz alternatywne klawiatury i myszki (Fedorowicz-Kruszewska, 2013, s. 106114). Należy jednak zaznaczyć, że w dostępie do informacji oprócz nowoczesnych technologii równie ważna jest umiejętność korzystania z nich oraz przetwarzania informacji. Księgozbiory obu bibliotek laskowskich przystosowane są przede wszystkim do publikacji brajlowskich oraz drukowanych i aby odpowiedzieć na nowe potrzeby czytelników, powinny uzupełniać swoje zbiory także o inne typy dokumentów - np. książki mówione, czy wydrukowane dużą czcionką. W kontekście nowych technologii niewątpliwym problemem są braki sprzętowe. TOnO w miarę swoich możliwości stara się zaspokajać potrzeby obu placówek w tym zakresie, choć do tej pory w niewystarczający sposób w kontekście wyzwań stojących przez obiema placówkami i ich roli w funkcjonowaniu tego ośrodka szkolno-wychowawczego.

Od lat obie biblioteki borykają się z ciągłymi brakami w obsadzie personalnej oraz brakiem fachowego przygotowania personelu, który nie posiada wykształcenia bibliotekarskiego oraz nie rozwija kompetencji w zakresie obsługi czytelnika z niepełnosprawnością wzroku. Stąd chociażby problemy z prowadzeniem dokumentacji i statystyk czytelników oraz niski poziom prowadzenia rozmaitych form pracy z użytkownikiem, który jest także efektem niewychodzenia naprzeciw ich oczekiwaniom i potrzebom. Plany pracy opracowywała biblioteka czarnodrukowa w 1. 2000-2005, wcześniej w niektórych latach były to jedynie "zamierzenia na przyszłość". Jak wspomniano, od jesieni 2016 r. w dziale wydawniczym pracuje osoba z wykształceniem bibliotekarskim.

Obie biblioteki potrzebują zmian w organizacji pracy, rozszerzenia oferty usług bibliotecznych, przeszkolenia pracowników, a także znacznego dofinansowania, które umożliwiłoby przystosowanie ich do współczesnych wymogów stawianych przed placówkami w głównej mierze obsługującymi czytelników z niepełnosprawnością wzroku. Obie placówki muszą bowiem zmierzyć się aktywnie z problemem spadku czytelnictwa, a biblioteka brajlowska w szczególności. Niedawna reorganizacja placówek, obejmująca także dział wydawniczy, powinna z czasem wpłynąć na zmianę stylu ich pracy. Obecnie podlegają one dyrektorowi Ośrodka Szkolno-Wychowawczego. Należy przy tym podkreślić ogromny wysiłek finansowy TOnO włożony w prowadzenie działalności wydawniczej, dzięki której biblioteka brajlowska każdego roku wzbogaca się o nowe tytuły.

Na koniec cytat z Heleny Radlińskiej: „Książka nie powinna czekać, aż jej zażądają, powinna być wciąż podsuwana czytelnikowi przed oczy" (Radlińska, 1961, s. 105). Wydaje się, że słowa te powinny przyświecać 
zmianom w obu bibliotekach i ich otoczeniu, by stały się dla uczniów i pracowników Lasek swoistym tzw. trzecim miejscem, czyli takim, w którym po internacie / domu oraz szkole / pracy, chętnie spędzaliby czas na nauce i rozrywce.

\section{BIBLIOGRAFIA}

Adaszyńska, Ewa; Kuncewicz, Małgorzata (2013). Czytelnik niepełnosprawny w środowisku akademickim. Oferta biblioteczna dla osób niewidomych z dysfunkcją wzroku na przykładzie Zielonogórskiej Biblioteki Cyfrowej. Zarzadzanie Biblioteka. Library Management, nr 1, s. 51-71.

Chamera-Nowak, Agnieszka (1998). Książka w działalności Zakładu dla Niewidomych w Laskach w latach 1910-1994. Acta Universitatis Wratislaviensis, Bibliotekoznawstwo, nr 21, s. 62-67.

Chamera-Nowak, Agnieszka (2006). Zespół biblioteczny Zakładu dla Niewidomych w Laskach. Acta Universitatis Wratislaviensis Bibliotekoznawstwo, nr 26, s. 153-168.

Chamera-Nowak, Agnieszka (2016). Wpływ technologii na produkcję książki brajlowskiej na przykładzie Towarzystwa Opieki nad Ociemniałymi w Laskach. Acta Poligrahica, nr 7, s. 49-65.

[Czacka, Elżbieta] (1913). Objaśnienie pisowni dla ociemniałych. Warszawa: TOnO.

[Czacka, m. Elżbieta] (1930). Prawidła przepisywania ksiażek dla niewidomych. Warszawa: TOnO.

Czacka, Elżbieta (1934/1935). Książka niewidomego. Referat Wygłoszony na II Polskim Zjeździe Nauczycieli Szkół Specjalnych w Warszawie, w dniach od 4 do 6 października 1934 r. Szkoła Specjalna, nr 2/4, s. 108-122. Przedruk W: E. Czacka, O niewidomych, oprac. M. Banaszek, T. 3, Warszawa, Wydaw. UKSW, 2008, s. 117-153.

Czacka, Elżbieta (1935). Historia i zarys organizacyjny „Dzieła Lasek”, Laski - Różanna, 8 czerwca 1935 r. (mps. Bibl. Tyfl., Laski).

Czacka, Elżbieta; Landy, Teresa (1931). System Braille’a w Polsce. Szkoła Specjalna, nr 4, s. 197-204. Przedruk.

Czerwińska, Małgorzata (1999). Pismo i książka w systemie L. Braille’a w Polsce. Historia i funkcje rewalidacyjne. Warszawa: SBP.

Czerwińska, Małgorzata (2003a). Książka niewidomego - od pisma wypukłego do postaci elektronicznej. Roczniki Biblioteczne, R. 47, s. 121-139.

Czerwińska, Małgorzata (2003b). Książka niewidomego. W: Encyklopedia pedagogiczna XXI wieku, t. 2, G-€, Warszawa: Wydaw. Akademickie „Żak”, s. 849-858.

Czerwińska, Małgorzata (2004). Nowoczesne formy dostępu osób niewidzących do słowa pisanego. W: Biblioterapia - z zagadnień pomocy niepetnosprawnym użytkownikom ksiażki. Red. M. Fedorowicz, T. Kruszewski, Toruń: Wydaw. Naukowe UMK, s. 101-126.

Czerwińska, Małgorzata (2011). Od Braille'a do DAISY - o czytaniu i czytelnictwie osób z niepełnosprawnościa wzroku. W: Czytanie, czytelnictwo, czytelnik. Red. A. Żbikowska- Migoń, współudz. A. Łuszpak. Wrocław: Wyd. UWr, s. 173-188.

Czerwińska, Małgorzata (2015). System Braille’a - rewolucja medialna czy inkluzja społeczna osób z niepełnosprawnością wzroku? Przeglad Biblioteczny, z. 3, s. 365-381.

Fedorowicz, Małgorzata (2010). Człowiek niepetnosprawny w bibliotece publicznej. Toruń: Wydaw. Naukowe UMK. 
Fedorowicz, Małgorzata (2014). Jakość bibliotek obsługujących osoby z niepełnosprawnością - przegląd instrumentów badawczych. Przegląd Biblioteczny, z. 2, s. 410-419.

Fedorowicz-Kruszewska, Małgorzata (2013). Biblioteki wobec wykluczenia informacyjnego osób niepełnosprawnych - współczesne tendencje. W: Biblioteka w komórce? Przyszłość ustug bibliotecznych. Red. M. Wrocławska i J. Jerzyk-Wojtecka, Łódź: Biblioteka Uniwersytetu Łódzkiego, s. 106-114.

Fedorowicz-Kruszewska, Małgorzata; Cyrklaff, Magdalena J. (2016). Media w środowisku osób zagrożonych wykluczeniem społecznym. Toruń: Wyższa Szkoła Bankowa w Toruniu.

Gorajewska, Danuta; Paplińska, Małgorzata (2007). Niewidomy czytelnik - fakty i mity związane z dostępem do tekstu pisanego. W: Biblioterapia. Z zagadnień pomocy niepetnosprawnym użytkownikom książki. Red. M. Fedorowicz i T. Kruszewski, T. 2, Toruń: Wydaw. UMK, 2007, s. 67-83.

Gościmska, Alicja (1982). Dzieło Lasek podczas okupacji hitlerowskiej. Laski: TOnO.

Gościmska, Alicja (2014). Torowała nowe drogi niewidomym. Róża Czacka-Matka Elżbieta jako tyflolog i wychowawca. Wyd. 2 popr., Laski: TOnO.

Hardisty, Jon; Mundt, Sebastian (2012). Key Performance Indicator Handbook for Libraries Serving Print Disabled People, [online]. IFLA; [dostęp: 26.03.2017]. Dostępny w WWW: $<$ https://www.ifla.org/publications/key-performance-indicator-handbook-for-libraries-serving-print-disabled-people>.

Jakubowski, Stanisław (2005). Wtórny analfabetyzm skutkiem odejścia od pisma brajla. W: Uczeń niewidomy i stabo widzacy w ogólnodostępnej szkole średniej. Poradnik dla nauczycieli szkół ogólnodostępnych. Red. S. Jakubowski. Warszawa: Ministerstwo Edukacji Narodowej i Sportu, s. 156-158.

Józefowicz, Tadeusz; Saloni, Zygmunt (1991). System polskich ortograficznych skrótów brajlowskich, omówienie systemu i jego historia. Warszawa: Redakcja Wydawnictw Tyflologicznych. Zakład Wydawnictw i Nagrań PZN.

Kaczmarek, Anna, oprac. red. (2003). Nowoczesne techniki kształcenia dzieci niewidomych i stabo widzących. Europejska Konferencja Owińska 25-26.04.2003 r. Poznań. Poznań: Wydaw. eMPI ${ }^{2}$.

Kuczyńska-Kwapisz, Jadwiga (2011). Wkład Matki Elżbiety Róży Czackiej w rozwój tyflologii w kontekście wspótczesnej recepcji jej myśli. Warszawa: Wydaw. UKSW.

Laski. Sprawozdanie z działalności Towarzystwa Opieki nad Ociemniałymi [1922-1938] (1938). Warszawa: TOnO.

Mazowiecki, Tadeusz, oprac. (2000). Ludzie Lasek. Wyd. 2. Warszawa: Biblioteka „Więzi”. Paplińska, Małgorzata (2005). Brajl w nowoczesnych technologiach - kierunki przemian w edukacji i komunikacji niewidomych. W: Społeczeństwo równych szans. Tendencje i kierunki zmian, red. B. Gorajewska. Warszawa: Stowarzyszenie Przyjaciół Integracji, s. $174-181$.

Paplińska, Małgorzata (2008). Przyszłość pisma Braille’a - rozwój czy schyłek? W: Niewidomi w świecie ksiażek i bibliotek. Wybrane zagadnienia. Red. M. Czerwińska i T. Dederko. Warszawa, s. 53-62.

Paplińska, Małgorzata (2015a). Młode pokolenie osób z niepełnosprawnością wzroku w paradoksie informacyjno-komunikacyjnym. W: Tyflopedagogika wobec współczesnej przestrzeni edukacyjno-rehabilitacyjnej. Red. K.Czerwińska, M. Paplińska, M. Walkiewicz-Krutak, Warszawa. Wydaw. APS, s. 136-155.

Paplińska, Małgorzata (2015b). Niewidomy czytelnik - cyfrowy tubylec czy brajlowski analfabeta? O kryzysie umiejętności czytania dotykowego. W: Tyflopedagogika wobec 
współczesnej przestrzeni edukacyjno-rehabilitacyjnej. Red. K. Czerwińska, M. Paplińska, M. Walkiewicz-Krutak, Warszawa. Wydaw. APS, s. 179-195.

Protokoły zniszczeń oraz korespondencja Zakładu w Laskach z Dyrekcją Okręgu Poczty i Telekomunikacji w Warszawie oraz Rejonowym Urzędem Poczty Warszawa-Województwo z 1987 r. (1987). (mps. Dział Braille'a, Laski).

Przybył-Sadowska, Elżbieta (2015). Triuno. Instytucje we wspólnocie Lasek 1911-1961. Kraków: Libron.

Radlińska, Helena (1922). Jak prowadzić bibioteki wędrowne: wskazówki i przykłady. ToruńWarszawa-Siedlce: Towarzystwo Wydawnicze „Ignis”.

Radlińska, Helena (1961). Zagadnienia bibliotekarstwa i czytelnictwa. Wstęp i opr. I. Lepalczyk, Wrocław- Warszawa-Kraków: Zakład Narodowy im. Ossolińskich.

Rakowska, Alicja (2007). Tyflologia, tyflopsychologia, tyflopedagogika. W: Encyklopedia pedagogiczna XXI wieku. T. 6 Su-U. Warszawa: Żak, s. 866-869.

Regulamin Biblioteki Brajlowskiej, 10.VI.1931, Laski-Różanna (1931). (mps. Dział Braille'a, Laski).

Rocznik Zarządu Towarzystwa Opieki nad Ociemniałymi w Królestwie Polskiem za pierwszy okres działalności od dnia 1 grudnia 1911 do dnia 31 grudnia 1912 (1913). Warszawa: TOnO.

Rocznik Zarzadu Towarzystwa Opieki nad Ociemniatymi w Królestwie Polskiem za drugi okres działalności od dnia 1 stycznia 1913 do dnia 31 grudnia 1913 (1914). Warszawa: TOnO.

s. Cecylia [Z. Gawrysiak] (1991). Róża Czacka - Matka Elżbieta w XXX rocznice śmierci. Warszawa: PZN.

Sprawozdania z działalności Biblioteki Czarnodrukowej za lata 1981-2016 (1981-2016). (mps. Bibl. Czarnodrukowa, Laski).

Sprawozdania z pracy Biblioteki Brajlowskiej za lata 1973-2016 (1973-2016). (msp. Dział Braille'a, Laski).

Sprawozdanie z działalności Towarzystwa Opieki nad Ociemniałymi i prowadzonych przezeń zakładów za okres od 1 kwietnia 1936 r. do 31 marca 1937 r. (1936/1937). (mps. Bibl.. Tyfl., Laski).

Sprawozdanie z działalności Towarzystwa Opieki nad Ociemniałymi za 1953 r. (1953). (mps. Bibl. Tyfl., Laski).

Statut Towarzystwa Opieki nad ociemniałymi w Królestwie Polskim (1911).[Warszawa]: Towarzystwo Opieki nad Ociemniałymi w Królestwie Polskim.

Villey, Pierre (1977). Niewidomy dobroczyńca niewidomych, Maurycy de la Sizeranne. W: Wypisy tyflologiczne. Wybrała i oprac. s. C. Gawrysiak, cz. 1. Warszawa: ATK, s. 43-66. W: E. Czacka, O niewidomych. Oprac. M. Banaszek, Warszawa, Wydaw. UKSW, 2008, s. 117-153.

Wyrzykowska, Zofia (2002). Historia 50-letniej działalności 1910-1960 Towarzystwa Opieki nad Ociemniałymi w Laskach. Laski: TOnO.

Zarządzenie Ministerstwa Wyznań Religijnych i Oświecenia Publicznego z dn. 24 maja 1934 r. nr IIP-3133/34 o wprowadzeniu w szkołach specjalnych dla niewidomych polskiego alfabetu oraz skrótów ortograficznych (1934).

Zybert, Elżbieta Barbara (2007), Jakość w działalności bibliotek: oceny - pomiary - narzędzia. Warszawa: Centrum Edukacji Bibliotekarskiej, Informacyjnej i Dokumentacyjnej.

Żółtowski, Michał (1999). Blask prawdziwego światła. Matka Elżbieta Róża Czacka i jej dzieło. Lublin: Er-Art.

Artykut w wersji poprawionej wpłynat do Redakcji 7 lipca 2017 r. 
AGNIESZKA CHAMERA-NOWAK

Faculty of Journalism, Information and Book Studies

The University of Warsaw

e-mail: achamera@uw.edu.pl

\section{BRAILLE AND NON-TACTILE LIBRARY OF THE INSTITUTE FOR THE BLIND IN LASKI, POLAND}

KEYWORDS: The Institute for the Blind in Laski. Braille library. Non-tactile library. Visually impaired readers. Braille books. Readership.

ABSTRACT: Thesis/Objective - Braille and non-tactile library of the Institute for the Blind in Laski are both public and school libraries the services of which are addressed to visually impaired readers. Their users are various types of pupils and students as well teachers, tutors and other staff of Laski Institute (including the retired staff) and their families which results in a very broad coverage of the library resources as regards topics and level of education. The article is intended to present both libraries with focus on the services they offer to visually impaired people and problems they face in the era of Internet, fast development of IT for the visually impaired and decreasing readership, in particular the readership of Braille books. Research method - The current activity of both libraries was assessed with the template for the libraries adjusted to the needs of the disabled users including: the facility and the equipment, library resources, assistive technologies, library services and staff skills. The author analyzed primary and secondary sources with focus on the library documentation, in particular meeting minutes and library reports. The article covers a brief history of both libraries and their current activities. In order to assess their services for the visually impaired the author used a template she designed based on the international solutions and IFLA guidelines (Fedorowicz, 2010). Results/Conclusions - The activity of both Laski libraries is quite specific as it goes beyond the regular educational activity of Laski schools. Their users are both students and teachers, tutors and other staff, including their families and the retired staff which results in a very broad coverage of the library collection. As a result, they are both public and school libraries, addressing their services mostly to the visually impaired people, which is reflected in their resources, covering vast majority of topics and levels of education. In the era of Internet, IT solutions for the visually impaired and decreasing readership, in particular the readership of braille books, both libraries faced new challenges related to the expectations of their users who are keen on easy access to information unlimited with time and space and available in most convenient format. 